\title{
Purification and Characterization of the Quinoprotein D-Glucose Dehydrogenase Apoenzyme from Escherichia coli
}

\author{
Minoru Ameyama, Masatsugu Nonobe, Emiko Shinagawa, \\ Kazunobu Matsushita, Koichi TaKimoto* \\ and Osao ADACHI \\ Laboratory of Applied Microbiology, Department of Agricultural Chemistry, \\ Faculty of Agriculture, Yamaguchi University, Yamaguchi 753, Japan \\ * Radioisotopes Laboratory, Yamaguchi University, \\ Yamaguchi 753, Japan
}

Received May 13, 1985

\begin{abstract}
Purification and characterization of the quinoprotein D-glucose dehydrogenase (EC 1.1.99.17) from Escherichia coli $\mathrm{K}-12$ were carried out, and the purified enzyme was obtained as the apo-form. The enzyme was purified 1,400-fold with an overall yield of $28 \%$ from the membrane fraction of the organism by a procedure involving solubilization of the enzyme with Triton X-100, ion exchange chromatographies and gel filtration. The homogeneity of the enzyme was confirmed by SDSpolyacrylamide gel electrophoresis and analytical ultracentrifugation, and its molecular weight was estimated to be 88,000 . The purified enzyme itself had no enzyme activity, but it was markedly activated on the addition of pyrroloquinoline quinone in the presence of magnesium ions. The enzyme showed a broad substrate specificity for various monosaccharides including D-glucose, Dfucose, D-galactose, D-mannose and D-xylose. Oxidation of substrates proceeded rapidly at fairly acidic $\mathrm{pH}$ with ubiquinone, which may be the intrinsic electron acceptor of the organism. EDTA, $p$ benzoquinone, citrate and semicarbazide showed inhibitory effects on the enzyme activity. The stability as to $\mathrm{pH}$ and heating was increased when the enzyme was converted to the holo-enzyme.
\end{abstract}

In D-glucose metabolism of Escherichia coli, it is generally thought that D-glucose is taken up into the cell through a phosphoenolpyruvate dependent phosphotransferase system and subsequently metabolized through the pentose phosphate pathway or Embden-Meyerhof pathway and the Krebs cycle. In oxidative bacteria like Gluconobacter sp., ${ }^{1 \sim 7)}$ membrane-bound quinoprotein Dglucose dehydrogenase (GDH), catalysis of the direct oxidation of $\mathrm{D}$-glucose, is predominant and, to a lesser extent, D-glucose is transferred to the cytoplasm and further metabolized through the predominantly developed pentose phosphate pathway. Recently, we found, however, that GDH widely exists in not only oxidative bacteria but also in other nonoxidatives, when the enzyme activity was assayed in the presence of pyrroloquinoline quinone (PQQ). ${ }^{8)} \mathrm{GDH}$ in various microor- ganisms commonly exists as the apo-form and is activated by PQQ, except for in acetic acid bacteria, in which the enzyme is usually present as the holo-form. To date, most investigations on GDH have been performed with oxidative bacteria such as Gluconobacter suboxydans, ${ }^{9)}$ and some oxidative bacteria such as Pseudomonas fluorescens ${ }^{10)}$ and Acinetobacter calcoaceticus, ${ }^{11,12)}$ in which the holo-enzyme is predominant. They have been purified as holo-enzymes. It was thought worth attempting to purify GDH from $E$. coli as the apoform and to compare it with those from other microbial sources. In this paper, the purification and some enzymatic properties of the purified apo-GDH are reported.

\section{MATERIALS AND METHODS}

Materials. Authentic PQQ was purified from a culture 
of a methylotrophic bacterium as reported previously. ${ }^{13)}$ Hydroxyapatite was prepared by the procedure of Tiselius et al. ${ }^{14)}$ Amphytol 20B-S was a kind gift from Kao Co. Ubiquinones were kind gifts from Eizai Co. and Nissin Seifun Co. DNase (EC 3.1.4.5) and RNase (EC 3.1.4.22) were products of Sigma Chemicals Co. Other reagents used in this study were commercial products of guaranteed grade.

Bacterial strain and growth conditions. E. coli $\mathrm{K}-12$ AKU 0008 was kindly supplied from the type culture collection of the Faculty of Agriculture, Kyoto University (AKU), for this study. The organism was grown on a medium composed of $3.5 \mathrm{~g}$ of $\mathrm{Na}\left(\mathrm{NH}_{4}\right) \mathrm{HPO}_{4}, 2 \mathrm{~g}$ of citric acid, $10 \mathrm{~g}$ of $\mathrm{K}_{2} \mathrm{HPO}_{4}$ and $10 \mathrm{ml}$ of mineral mixture ${ }^{15)}$ in a total volume of $990 \mathrm{ml}$ of tap water, which was autoclaved at $120^{\circ} \mathrm{C}$ for $30 \mathrm{~min}$, and to which $10 \mathrm{ml}$ of sterile D-glucose $(5 \mathrm{~g})$ was then added. Other growth conditions were the same as reported previously. ${ }^{16)}$ Bacterial cells were harvested at the stationary phase by centrifugation, washed twice with distilled water and stored at $-30^{\circ} \mathrm{C}$ until use.

Analytical procedure and enzyme assay conditions. The protein content was determined as described by Dulley and Grieve ${ }^{17)}$ using bovine serum albumin as the standard. D-Glucose dehydrogenase activity was assayed in the presence of phenazine methosulfate (PMS) and 2,6-dichlorophenolindophenol (DCIP) under essentially the same conditions as reported previously. ${ }^{10,18,19)}$ The enzyme activity was expressed as the amount of enzyme which catalyzed the reduction of $1 \mu \mathrm{mol}$ DCIP per min under these conditions.

Holo-enzyme formation. Conversion of the apo-enzyme to the holo-enzyme was performed by essentially the same method as described previously. ${ }^{8)}$ To the enzyme solution, 2 volumes of $0.1 \mathrm{M}$ potassium phosphate, $\mathrm{pH} 6.5,1$ volume of $10 \mathrm{~mm} \mathrm{MgSO} 4 \cdot 7 \mathrm{H}_{2} \mathrm{O}$ and up to $7 \mu \mathrm{M}$ PQQ were added. Each mixture was incubated at $25^{\circ} \mathrm{C}$ for at least $10 \mathrm{~min}$ and a portion of the mixture was used for the enzyme activity assay.

SDS-Polyacrylamide gel electrophoresis. The homogeneity and molecular weight of the purified enzyme were determined by SDS-polyacrylamide gel electrophoresis as described by Laemmli. ${ }^{20)}$ A slab gel composed of a $5 \%$ stacking gel and a $10 \%$ separating gel was used. Other operations were carried out under the same conditions as reported previously. ${ }^{10)}$

Analytical ultracentrifugation. Estimation of purity and examination of sedimentation velocity of the purified enzyme was carried out with a Spinco model E analytical ultracentrifuge operated at $59,780 \mathrm{rpm}$ using a schlieren optics. Temterature was maintained at $20^{\circ} \mathrm{C}$ throughout the measurement.
Solubilization and purification of GDH. Potassium phosphate buffer (KPB), pH 6.8, was used throughout the purification, and all procedures were carried out at $0 \sim 4^{\circ} \mathrm{C}$ unless otherwise stated. Preparation and storage of the membrane fraction were performed under essentially the same conditions as reported previously, ${ }^{10)}$ except that the buffer concentration was changed to $5 \mathrm{~mm}$ and $\mathrm{MgCl}_{2}$ was omitted. Addition of DNase and RNase to $10 \mu \mathrm{g}$ per ml each to the cell suspension was performed before cell disruption. Centrifugation to remove intact cells was carried out at $6,000 \times g$. The membrane fraction was finally obtained by centrifugation at $80,000 \times g$ for $90 \mathrm{~min}$ and stored at $-30^{\circ} \mathrm{C}$ until use. The membrane fraction was suspended in $5 \mathrm{~mm} \mathrm{KPB}$ to $10 \mathrm{mg}$ of protein per $\mathrm{ml}$ and then Triton $\mathrm{X}-100$ was added to $1 \%$ in the presence of $0.05 \mathrm{M} \mathrm{KCl}$. The mixture was incubated for $2 \mathrm{hr}$ with stirring and then centrifuged at $80,000 \times g$ for $90 \mathrm{~min}$. The supernatant was used as the solubilized enzyme solution. After the enzyme solution was applied to a DEAEcellulose column $(6 \times 15 \mathrm{~cm})$, which had been equilibrated with $5 \mathrm{~mm}$ KPB containing $0.1 \%$ Triton X-100, 0.1 M Dglucose and $0.05 \mathrm{M} \mathrm{KCl}$, the column was washed with an adequate volume of the same buffer and then the enzyme was eluted with the buffer containing $0.15 \mathrm{M} \mathrm{KCl}$. The buffer solutions used for the enzyme purification hereafter all contained $0.1 \%$ Triton $\mathrm{X}-100$ and $0.1 \mathrm{M}$ D-glucose unless otherwise stated. The enzyme active fractions were pooled and the $\mathrm{KCl}$ concentration was reduced to below $0.05 \mathrm{M}$ by diluting the enzyme solution with the buffer, which allowed adsorption of the enzyme by ion exchangers. The diluted enzyme solution was adsorbed onto another DEAE-cellulose column $(4 \times 10 \mathrm{~cm})$, which had been prepared as above. After the column had been washed with the buffer, the enzyme was eluted with $600 \mathrm{ml}$ of a linear gradient of 0.05 to $0.2 \mathrm{M} \mathrm{KCl}$ in the buffer. Then, DEAE-Toyopearl $650 \mathrm{M}$ column chromatography was carried out with a column size of $5 \times 5 \mathrm{~cm}$. The enzyme was eluted with an increasing linear concentration gradient of $\mathrm{KCl}$, from 0.05 to $0.3 \mathrm{M}$. The eluted enzyme solution was applied to a hydroxyapatite column $(2 \times$ $2 \mathrm{~cm}$ ), which had been equilibrated with $5 \mathrm{~mm}$ KPB containing $0.05 \mathrm{M} \mathrm{KCl}$. The enzyme activity passed through the column and some critical impurities which could not be eliminated by ion exchange chromatography were removed through adsorption on the column. The enzyme solution was adsorbed to a small volume of DEAEToyopearl gel and then eluted with a minimum volume of $\mathrm{KPB}$ containing $0.2 \mathrm{M} \mathrm{KCl}$ to concentrate the enzyme solution to less than $10 \mathrm{ml}$. The concentrated enzyme solution was then applied to a Toyopearl gel HW-60 (superfine) column $(4 \times 47 \mathrm{~cm})$ and passed through the column with $5 \mathrm{~mm}$ KPB. About a half of the total protein was separated as impurities at this step. The enzyme solution from the preceding step was applied onto a DEAE-Toyopearl column $(1.5 \times 5 \mathrm{~cm})$ and eluted with $100 \mathrm{ml}$ of a linear gradient of 0.05 to $0.3 \mathrm{M} \mathrm{KCl}$. At this step, a symmetrical elution peak of protein was seen 
accompanying the corresponding enzyme activity. It appeared that the enzyme was purified to a highly homogeneous state.

\section{RESULTS}

Purification of GDH from E. coli membrane

Solubilization of apo-GDH from the E. coli membrane was examined with various detergents. Of the tested detergents, $\beta$-octylglucoside, Mega and Triton X-100 solubilized the enzyme well. There were some differences in the enzyme stability during storage of the solubilized enzyme and Triton X-100 was found to be the best among these three detergents. Amphytol 20B-S and $N$-lauroylsarcosinate also solubilized GDH but, at the same time, a lot of contaminating proteins were solubilized. So, they appeared to be unfavorable for enzyme solubilization and further purification. Deoxycholate was also found to be useless. Other detergents including Brij and Tween series were not effective in solubilizing the enzyme.

About $58 \%$ of the original membrane GDH activity was recovered in the supernatant when the membrane was treated with $1 \%$ Triton $\mathrm{X}$ 100 in the presence of $0.05 \mathrm{M} \mathrm{KCl}$. The enzyme was stably purified in the presence of Triton X100 by a procedure involving ion exchange chromatographies, adsorption of impurities on hydroxyapatite and gel filtration, though the enzyme existed as the apo-form throughout the purification process. An overall yield of $28 \%$ was obtained with the finally purified enzyme, which showed 1400 -fold purification over the membrane fraction, as shown in Table I.

\section{Homogeneity and molecular weight of GDH}

On SDS-polyacrylamide gel electrophoresis, the purified GDH showed a single band which clearly indicated the homogeneity of the enzyme preparation (Fig. 1). It migrated a little faster than phosphorylase b (mol wt. 93,000) and slower than bovine serum albumin (mol. wt. 68,000). The apparent molecular weight of the enzyme in SDS was estimated to be 88,000 daltons relative to the marker proteins. The sedimentation pattern in analytical ultracentrifugation (Fig. 2) also showed homogeneity of the enzyme preparation and showed an apparent sedimentation constant calculated to be $3.7 \mathrm{~S}$, supporting the probability of the apparent molecular weight of the enzyme. As will be discussed later, the enzyme was found to exist as a monomer in SDS and also in Triton X-100.

\section{Activation of $G D H$ by $P Q Q$ and magnesium ions}

Activation of GDH was examined under various conditions as shown in Table II. GDH activity was not seen when the enzyme was assayed alone. A relatively small extent of enzyme activation was observed on the addition of only PQQ to the mixture for holoenzyme formation. Addition of both PQQ and magnesium ions led to complete activation of the enzyme. FAD and FMN could not be the

Table I. Summary of Purification of Apo-D-glucose Dehydrogenase From Escherichia coli

\begin{tabular}{lcccc}
\hline \multicolumn{1}{c}{ Step } & $\begin{array}{c}\text { Protein } \\
(\mathrm{mg})\end{array}$ & $\begin{array}{c}\text { Enzyme } \\
\text { activity } \\
\text { (units) }\end{array}$ & $\begin{array}{c}\text { Specific } \\
\text { activity } \\
\text { (units/mg) }\end{array}$ & $\begin{array}{c}\text { Purification } \\
\text { (fold) }\end{array}$ \\
\hline Membrane fraction & 6,280 & 1,425 & 0.2 & 1 \\
Solubilized fraction & 1,245 & 830 & 0.7 & 3 \\
DEAE-Cellulose I & 255 & 725 & 2.8 & 14 \\
DEAE-Cellulose II & 83 & 630 & 7.6 & 38 \\
DEAE-Toyopearl I & 21 & 620 & 29.5 & 148 \\
Hydroxyapatite & 9 & 480 & 53.3 & 266 \\
Toyopearl HW-60s & 4 & 450 & 112.5 & 563 \\
DEAE-Toyopeari II & 1.4 & 400 & 285.7 & 1,430 \\
\hline
\end{tabular}




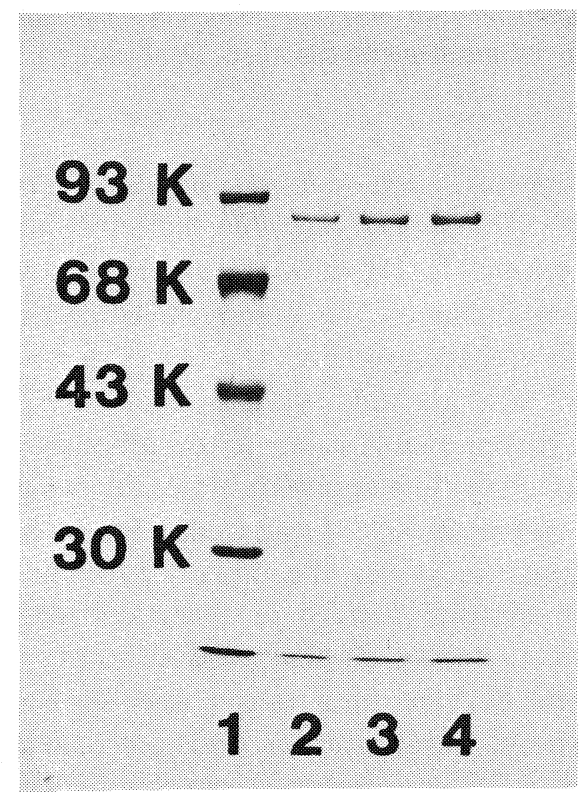

FIG. 1. SDS-Polyacrylamide Gel Electrophoresis of Apo-D-glucose Dehydrogenase from E. coli.

The purified enzyme with a specific activity of 285.7 was treated with $2 \%$ SDS and 5\% 2-mercaptoethanol and then applied to truck in the SDS-polyacrylamide gel. Lane 1, standard marker proteins: phosphorylase $b$ (mol. wt. $93 \mathrm{~K})$, bovine serum albumin $(68 \mathrm{~K})$, ovalbumin $(43 \mathrm{~K})$ and carbonic anhydrase $(30 \mathrm{~K})$; lane $2,2 \mu \mathrm{g}$ of the purified enzyme; lane $3,3 \mu \mathrm{g}$ of the purified enzyme; lane $4,4 \mu \mathrm{g}$ of the purified enzyme.

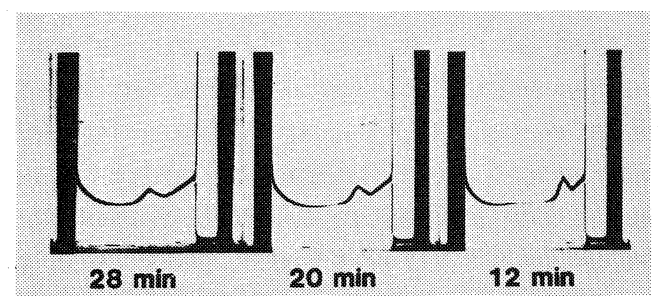

FIG. 2. Sedimentation Pattern of Purified Apo-Dglucose Dehydrogenase upon Analytical Ultracentrifugation.

The purified enzyme with a specific activity of 285.7 was used at a protein concentration of $6.5 \mathrm{mg}$ per $\mathrm{ml}$. Photographs were taken at $12 \mathrm{~min}, 20 \mathrm{~min}$ and $28 \mathrm{~min}$ after reaching $59,780 \mathrm{rpm}$ as indicated. Sedimentation was from right to left.

prosthetic group of the enzyme. Unlike in the case of methanol dehydrogenase, ${ }^{21,22)}$ the presence of ammonium ions in the reaction mixture had no effect on the enzyme activation.
Table II. Activation OF ApO-D-Glucose DEHYDROGENASE

The purified enzyme $(10 \mu \mathrm{g})$ with a specific activity of 285.7 was used and the enzyme activity was assayed at $\mathrm{pH}$ 6.5 with PMS-DCIP. The activation of apo-D-glucose dehydrogenase was examined under various conditions as indicated. $\mathrm{MgSO}_{4}$ was added to $2.5 \mathrm{mM}$. PQQ and both FAD and FMN were added to $7 \mu \mathrm{M}$ and $10 \mu \mathrm{M}$, respectively. The enzyme activity was expressed as the relative activity, and the reaction rate of $2.8 \mu \mathrm{mol}$ of Dglucose oxidized per min observed with the activation system (4) was taken as $100 \%$.

\begin{tabular}{llc}
\hline \multicolumn{1}{c}{ Activation system } & $\begin{array}{c}\text { Relative } \\
\text { activity } \\
(\%)\end{array}$ \\
\hline (1) & Enzyme & 0 \\
(2) & Enzyme $+\mathrm{MgSO}_{4}$ & 2.1 \\
(3) & Enzyme $+\mathrm{PQQ}$ & 17.1 \\
(4) & Enzyme $+\mathrm{MgSO}_{4}+\mathrm{PQQ}$ & 100 \\
(5) & Enzyme $+\mathrm{MgSO}_{4}+\mathrm{FAD}$ & 2.1 \\
(6) & Enzyme $+\mathrm{MgSO}_{4}+\mathrm{FMN}$ & 0 \\
(7) & $(4)+3.3 \mathrm{mM} \mathrm{NH}_{4} \mathrm{Cl}$ & 90.4 \\
\hline
\end{tabular}

Activation of GDH by PQQ and magnesium ions was largely dependent on the $\mathrm{pH}$ of the mixture during holo-enzyme formation. Rapid and complete holo-enzyme formation occurred at $\mathrm{pH} 6.5$ to 7.0 , at which the maximum activation was seen, which was comparable to the specific activity found for the purified enzyme. At $\mathrm{pH} 3.0$, the holo-enzyme formation proceeded to $40 \%$ of the extent at $\mathrm{pH}$ 7.0. In the region from $\mathrm{pH} 3.0$ to neutral $\mathrm{pH}$, the extent of holo-enzyme formation showed a linearly proportional increase. On the other hand, in the alkaline $\mathrm{pH}$ region, it became greatly reduced, and at $\mathrm{pH} 9.0$ holo-enzyme formation was no longer observed.

\section{Electron acceptor specificity}

The availability of electron acceptors for Dglucose oxidation was examined as summarized in Fig. 3. The reactivity and optimum $\mathrm{pH}$ varied with each electron acceptor employed. The highest oxidation rate was observed with PMS-DCIP, at pH 6.0 at which the enzyme showed specific activity corresponding to 327 units per mg of protein. The reaction rate was found to be decreased to about $23 \%$ and $21 \%$ 


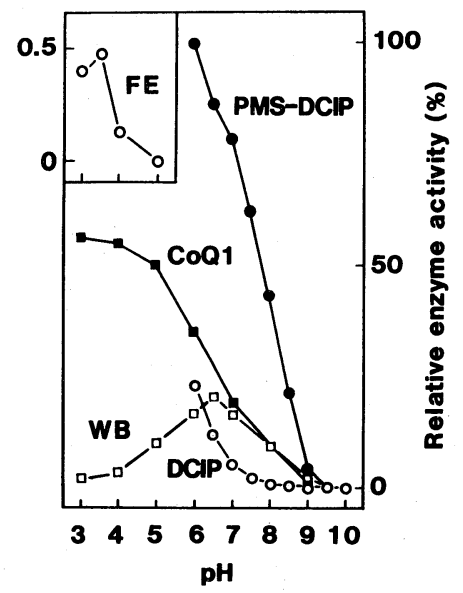

FIG. 3. Availability of Electron Acceptors for D-Glucose Oxidation.

The purified enzyme was used after conversion to the holo-form. The enzyme activity was measured in the presence of $0.4 \mathrm{mM}$ PMS and $0.22 \mathrm{~mm}$ DCIP (PMS-DCIP) in a reaction mixture at various pHs. DCIP denotes that the assay was carried out with DCIP alone in the absence of PMS. Instead of DCIP, $0.12 \mathrm{~mm}$ ubiquinone-1 $\left(\mathrm{CoQ}_{1}\right)$ or $0.17 \mathrm{~mm}$ Wurster's blue (WB) was used as the electron acceptor in the absence of PMS. The assay with ferricyanide (FE) was carried out as described previously. ${ }^{23)}$ The buffer solutions used were Na-acetate $(\mathrm{pH} 3 \sim 5)$ and potassium phosphate-sodium borate- $\mathrm{NaOH}(6 \sim 10)$.

the rate with PMS-DCIP when assayed with DCIP at pH 6.0 and Wurster's blue at 6.5, respectively. In the case of ubiquinone-1, the maximum oxidation rate was observed at $\mathrm{pH}$ 3.0. Ferricyanide was also found to act as an electron acceptor, although it showed the lowest oxidation rate of the tested compounds; about $0.5 \%$ the oxidation rate with PMSDCIP being observed at $\mathrm{pH}$ 3.5. The reactivity with ubiquinone-1, which acted in the acidic region and showed a considerable reaction rate, may reflect the situation in vivo: the enzyme is contained in the bacterial cytoplasmic membrane and oxidation of the substrate is coupled with the electron transport chain of the organism in which ubiquinone might play a role as the primary electron acceptor from $\mathrm{GDH}$ in D-glucose oxidation.

\section{Substrate specificity}

Oxidation of various substrates by the pu-
Table III. Substrate Specificity of D-Glucose Dehydrogenase

The purified enzyme with a specific activity of 285.7 was used. After the apo-enzyme had been converted to the holo-enzyme by preincubating the enzyme with PQQ in the presence of $\mathrm{MgSO}_{4}(2.5 \mathrm{~mm})$, a portion of the holoenzyme $(10 \mu \mathrm{g})$ was added to the reaction mixture and the reaction was carried out at $\mathrm{pH} 6.0$ with PMS-DCIP in the presence of individual substrates $(33 \mathrm{~mm})$. Relative enzyme activity was expressed as the percentage of that with D-glucose.

\begin{tabular}{lc}
\hline \multicolumn{1}{c}{ Substrate } & Relative activity $(\%)$ \\
\hline D-Glucose & 100 \\
D-Mannose & 37.7 \\
D-Galactose & 41.4 \\
D-Fucose & 90.9 \\
D-Fructose & 2.7 \\
L-Sorbose & 0 \\
L-Rhamnose & 20.0 \\
D-Ribose & 0 \\
D-Xylose & 53.6 \\
D-Arabinose & 0 \\
D-Gluconate & 0 \\
Maltose $^{a}$ & 10.0 \\
Lactose $^{a}$ & 0 \\
Sucrose & 0
\end{tabular}

a Substrate concentration was $17 \mathrm{~mm}$ in the reaction mixture.

rified GDH was examined as shown in Table III. The enzyme showed a broad substrate specificity and sugars including D-glucose, Dfucose, D-galactose, D-mannose, L-rhamnose and D-xylose were oxidized by the enzyme. Maltose was also oxidized to $10 \%$ the level of Dglucose oxidation. The apparent Michaelis constant for D-glucose with PMS-DCIP was estimated to be $0.9 \mathrm{~mm}$.

\section{Inhibitors of D-glucose oxidation}

The influence of a variety of reagents on the enzyme activity was examined, as summarized in Table IV. A remarkable inhibitory effect was observed with EDTA, citrate, $p$-benzoquinone and semicarbazide. EDTA and citrate acted as metal chelators and formed a chelate complex with magnesium, which in turn caused the release of PQQ from the enzyme which led to a loss of enzyme activity. $p$-Benzoquinone acted as an electron acceptor, $p$-hydro- 
TABle IV. EFFects of SeVEral Compounds on D-Glucose Dehydrogenase

The purified enzyme with a specific activity of 285.7 was incubated with the various compounds indicated at $25^{\circ} \mathrm{C}$ for $10 \mathrm{~min}$. PQQ was added to $7 \mu \mathrm{M}$ and the mixture was further incubated at $25^{\circ} \mathrm{C}$ for an additional $10 \mathrm{~min}$. The enzyme activity was measured with a portion of the enzyme solution at $\mathrm{pH} 6.5$ with PMS-DCIP. About $2.8 \mu \mathrm{mol}$ of D-glucose was oxidized in the control run.

\begin{tabular}{|c|c|c|}
\hline Compound & Concentration & $\begin{array}{c}\text { Relative } \\
\text { activity } \\
(\%)\end{array}$ \\
\hline Control & - & 100 \\
\hline Quinacrine- $\mathrm{HCl}$ & $0.1 \mathrm{~mm}$ & 52.5 \\
\hline$o$-Phenanthroline & $60 \mu \mathrm{M}$ & 114.7 \\
\hline$\alpha, \alpha^{\prime}$-Dipyridyl & $2 \mu \mathrm{M}$ & 116.8 \\
\hline EDTA & $3.3 \mathrm{~mm}$ & 0 \\
\hline Citrate & $10 \mathrm{~mm}$ & 14.3 \\
\hline$p$-Benzoquinone & $0.34 \mathrm{~mm}$ & 1.4 \\
\hline D-Gluconate & $33 \mathrm{~mm}$ & 74.5 \\
\hline $\mathrm{PCMBS}^{a}$ & $10 \mu \mathrm{M}$ & 108.4 \\
\hline $\mathrm{DTNB}^{a}$ & $1 \mathrm{~mm}$ & 103.6 \\
\hline Semicarbazide- $\mathrm{HCl}^{b}$ & $50 \mathrm{~nm}$ & 10.4 \\
\hline $\mathrm{CuSO}_{4}{ }^{a}$ & $2 \mathrm{~mm}$ & 0 \\
\hline $\mathrm{FeSO}_{4}{ }^{a}$ & $2 \mathrm{mM}$ & 0 \\
\hline
\end{tabular}

a The compounds were added at the concentrations indicated to the preincubation mixture with the enzyme and subsequently reduced about 30 -fold by adding the enzyme solution to the assay mixture.

${ }^{b}$ PQQ (1.43 mM) was mixed with an equimolar amount of semicarbazide- $\mathrm{HCl}$ followed by incubation at room temperature. The mixture was diluted 1,000-fold and a portion was incubated with the apo-enzyme. The relative enzyme activity was taken as that in the control run with $50 \mathrm{nM}$ PQQ.

quinone being formed, which prevented the electron flow to PMS, and thus it appeared to be an inhibitor. Semicarbazide, a typical carbonyl reagent, reacted with PQQ to form a Schiff base and inactivated PQQ as the prosthetic group in the enzyme reaction. Quinacrine and gluconate were somewhat inhibitory, although relative high concentrations were required for the enzyme activity to decrease with gluconate. $o$-Phenanthroline, $\alpha, \alpha^{\prime}$-dipyridyl, PCMBS and DTNB showed no inhibitory effects. Titration of the sulfhydryl group of the enzyme with both PCMBS and DTNB yielded no free sulfhydryl residues, with both the apo- and holo-

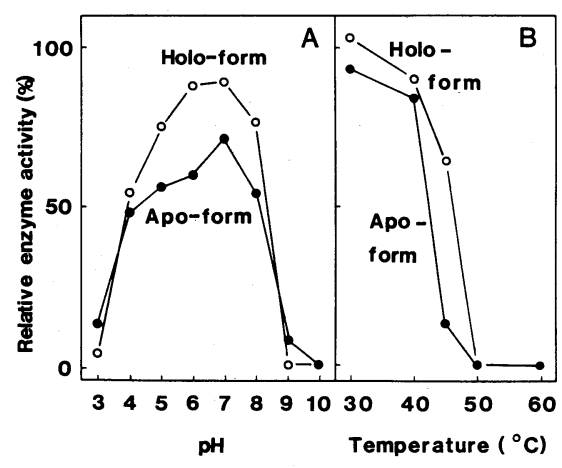

FIG. 4. Enzyme Stability as to $\mathrm{pH}$ and Temperature.

The stability as to $\mathrm{pH}$ (A) and temperature (B) was examined with the apo- and holo-enzymes. The enzyme was incubated in the mixture for holo-enzyme formation with PQQ (holo-form) or without PQQ (apo-form). A, The enzyme mixtures were added to the buffer solution at the $\mathrm{pHs}$ indicated. After 2 days, the residual enzyme activity was measured. B, The enzyme mixtures were heated for $10 \mathrm{~min}$ at various temperatures as indicated. Relative enzyme activity was expressed as the percentage of enzyme activity observed with the non-treated enzyme.

enzymes. Heavy metals such as copper and iron were also inhibitory.

\section{Thermostability and $p H$ stability of $G D H$}

As the enzyme was purified as the apo-form, whether there was any difference between the two forms of enzyme as to heating and $\mathrm{pH}$ was examined. As can be seen in Fig. 4, the stability of the enyzme was much improved on conversion of the apo-enzyme to the holoenzyme. The holo-enzyme was rather stable over a wide $\mathrm{pH}$ range; but the apo-enzyme also showed considerable enzyme activity, indicating that the apo-enzyme was not labile as to $\mathrm{pH}$. On the other hand, both types of the enzyme became inactivated upon heating over $50^{\circ} \mathrm{C}$. At $45^{\circ} \mathrm{C}$ for $10 \mathrm{~min}$, a striking difference was observed between the two forms of enzyme; while $60 \%$ of the original enzyme activity was retained by the holo-form, only $10 \%$ was retained by the apo-form.

\section{Effect of detergent on enzyme conformation}

As mentioned above, the enzyme migrated as a protein with a molecular weight of 88,000 daltons on SDS-polyacrylamide gel electro- 


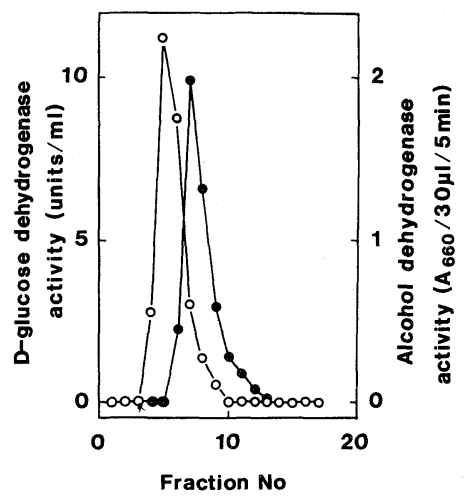

FIG. 5. Sucrose Density Gradient Centrifugation.

The purified enzyme (12 units) was applied to a $12 \mathrm{ml}$ linear sucrose gradient of 5 to $20 \%$ in $50 \mathrm{~mm} \mathrm{KPB}, \mathrm{pH} 6.5$, containing $0.1 \%$ Triton X-100. Alcohol dehydrogenase from acetic acid bacteria (mol. wt. 150,000) was used as the molecular weight reference. Centrifugation was performed at $160,000 \times g$ for $14.5 \mathrm{hr}$ with a Hitachi RPS-40T rotor. The gradient was fractionated into fractions of 25 drops $(0.45 \mathrm{ml} /$ tube $)$ from the top to the bottom. DGlucose dehydrogenase $(\bigcirc)$ and alcohol dehydrogenase (O) activities were monitored. Alcohol dehydrogenase activity measured with ferricyanide was plotted as the absorbance at $660 \mathrm{~nm}$.

phoresis (Fig. 1). The molecular weight of the enzyme was also estimated by sucrose density gradient centrifugation as shown in Fig. 5. In the presence of Triton X-100, the enzyme migrated to a position corresponding to a lower molecular weight than that of alcohol dehydrogenase of acetic acid bacteria (mol. wt. 150,000). ${ }^{24)}$ These results suggested that GDH might exist as a monomer in the presence of Triton X-100. In the absence of the detergent, the enzyme aggregated and became less active. Sucrose density gradient centrifugation was conducted with both the apo- and holoenzymes, and no differences were observed between them as to the effect of the detergent on the enzyme conformation.

\section{DISCUSSION}

Membrane-bound quinoprotein D-glucose dehydrogenase has been investigated in such microbial genera as Pseudomonas, ${ }^{10 \sim 12,25 \sim 27)}$ Gluconobacter, ${ }^{9,18,26 \sim 28)}$ Acinetobac- ter $^{11,12,25,29)}$ and Aspergillus. ${ }^{30,31)}$ Fairly good purification and characterization has been achieved for the enzymes from $G$. suboxydans $^{9)}$ and $P$. fluorescens. ${ }^{10)}$ This study was an attempt to determine whether there were any differences between the enzyme from $E$. coli and those from such these two bacteria. Another aim was to determine how stable the enzyme is, if it could be purified from the organism as the apo-enzyme.

Solubilization of the enzyme from the membrane was successfully achieved by use of Triton X-100, though complete solubilization of the enzyme activity could not be attained. Other detergents were not so effective as Triton X-100. As a result, the enzyme from $E$. coli, in which the enzyme originally existed as the apo-form, was relatively stably purified to a homogeneous state in spite of being the apoform. The degree of purification and overall yield were sufficient considering it was the apoform. Deletion of magnesium ions from the buffer solution used for enzyme purification allowed the enzyme to remain in the apo-form throughout the purification. This is the first example, to our knowledge, of a membranebound dehydrogenase being purified from a membrane as the apo-form. In the presence of magnesium ions and PQQ, the enzyme would be obtained as the holo-enzyme as in the case of the enzyme from a pseudomonad. ${ }^{10)} \mathrm{But}$ this is unlikely in the case of the enzyme from G. suboxydans, which usually exists as the holo-enzyme and is never resolved on deletion of magnesium ions. ${ }^{9)}$ The molecular weight of 88,000 daltons determined on SDSpolyacrylamide gel electrophoresis indicated the similarity of the molecular sizes of these enzyme preparations. The monomer of the $E$. coli enzyme was predominantly observed on sucrose density gradient centrifugation in the presence of Triton $\mathrm{X}-100$, similar to in the cases of the enzymes from $P$. fluorescens $^{10)}$ and $G$. suboxydans. ${ }^{9)}$ The enzyme was activated to the maximal extent when both PQQ and magnesium ions were incubated with the apoenzyme. FAD and FMN were inert as the prosthetic group. Oxidation of substrates pro- 
ceeded in the presence of dyes such as PMSDCIP, DCIP, Wurster's blue and even ferricyanide, which showed the lowest reactivity as an electron acceptor. As in the cases of already reported GDHs, ${ }^{9,10)}$ the optimum $\mathrm{pH}$ and reaction rate varied with the dye used. Of the tested electron acceptors, ubiquinone-1 showed a considerable reaction rate at acidic $\mathrm{pH}$ with a maximum at $\mathrm{pH}$ 3.0. The facts that ubiquinone is one of the naturally occurring electron acceptors in biological respiratory systems and D-glucose oxidation in oxidative bacteria proceeds in a fairly acidic region suggest that ubiquinone must function as the intrinsic primary electron acceptor in the $E$. coli respiratory chain during D-glucose oxidation in vivo. Indeed, as supporting evidence, the enzyme from $P$. fluorescens reduced longchained ubiquinones $\left(\mathrm{CoQ}_{2}\right.$ to $\left.\mathrm{CoQ}_{6}\right)$ as well as $\mathrm{CoQ}_{1}$ with high efficiency. Although sequential analysis of components of the electron transport system with respect to D-glucose oxidation has not been performed, it is quite probable that ubiquinone is the most intrinsic and direct electron acceptor. When $E$. coli was grown on agar plates of D-glucose-mineral medium containing $\mathrm{CaCO}_{3}$ in the presence or absence of $0.1 \mu \mathrm{g}$ PQQ per plate, a clear zone around the bacterial colony from the PQQ containing plate due to dissolution of $\mathrm{CaCO}_{3}$ caused by gluconate formation was observed, as commonly seen for acetic acid bacteria or other oxidative bacteria. Dissolution of $\mathrm{CaCO}_{3}$ on gluconate formation with $E$. coli has never been reported but it was seen in this study on conversion of the apo-enzyme to the holo-form on the addition of PQQ in vivo. Thus, it is not always impossible to perform gluconate fermentation with $E$. coli.

The substrate specificity of the enzyme showed similarities with that of the enzyme from $G$. suboxydans. It was also interesting to find that the $E$. coli enzyme showed a smaller Michaelis constant for D-glucose than those of the enzymes from the other two bacteria.

The substrate specificity of the enzyme showed similarities with that of the enzyme from $G$. suboxydans. It was also interesting to find that the $E$. coli enzyme showed a smaller Michaelis constant for D-glucose than those of the enzymes from the other two bacteria.

Magnesium ions are essential for holoenzyme formation. Deletion of the ions with a chelating agent resulted in conversion to the apo-enzyme and a simultaneous loss of enzyme activity. The restoration of the enzyme activity on the formation of the holo-enzyme with PQQ was specifically observed with magnesium ions, although other metal ions, $\mathrm{Co}^{2+}$ or $\mathrm{Ca}^{2+}$ were slightly effective in activating the apo-enzyme. ${ }^{8)}$ The relatively low activation observed with only PQQ could be due to that some magnesium ions must be involved in the apo-enzyme, because the original membrane fraction was not treated with EDTA. As has already been mentioned, ${ }^{8)}$ EDTA is a potent inhibitor of D-glucose oxidation. Carbonyl reagents were also found to be potent inhibitors through the formation of a Schiff base between PQQ and the inhibitors which prevented the prosthetic group from functioning in cyclic oxidoreduction as similarly mentioned by Duine et $a l .{ }^{32)}$ On the other hand, no critical sulfhydryl residues were detected on the surface of both the apo- and holo-enzymes, in agreement with the previous findings. ${ }^{9,10)}$ Other physicochemical properties of this apo-D-glucose dehydrogenase are now being investigated.

Acknowledgment. We are very grateful to Dr. H. Tanaka, Institute for Chemical Research, Kyoto University, for his generous provide and kind advice in use of analytical ultracentrifuge.

\section{REFERENCES}

1) T. E. King and V. H. Cheldelin, J. Biol. Chem., 198, 127 (1952).

2) T. E. King and V. H. Cheldelin, Biochim. Biophys. Acta, 14, 108 (1954).

3) J. G. Hauge, T. E. King and V. H. Cheldelin, J. Biol. Chem., 214, 11 (1955).

4) D. H. Bone and R. M. Hochster, Can. J. Biochem. Physiol., 38, 193 (1960).

5) V. H. Cheldelin, "Metabolic Pathways in Microorganisms," John Wiley and Sons, Inc., New York, 1961, p. 20. 
6) P. J. Le, V. Williams and C. Rainbow, J. Gen. Microbiol., 35, 237 (1964).

7) W. A. Wood, R. A. Fetting and B. C. Hertlein, "Methods in Enzymology," Vol. 5, ed. by S. P. Colowick and N. O. Kaplan, Academic Press, Inc., New York, 1962, p. 287.

8) M. Ameyama, M. Nonobe, M. Hayashi, E. Shinagawa, K. Matsushita and O. Adachi, Agric. Biol. Chem., 49, 1227 (1985).

9) M. Ameyama, E. Shinagawa, K. Matsushita and O. Adachi, Agric. Biol. Chem., 45, 851 (1981).

10) K. Matsushita, Y. Ohno, E. Shinagawa, O. Adachi and M. Ameyama, Agric. Biol. Chem., 44, 1505 (1980).

11) J. G. Hauge, “Methods in Enzymology," Vol. 9, ed. by W. A. Wood, Academic Press, Inc., New York, 1966, p. 92.

12) J. A. Duine, J. Frank Jr. and J. K. Van Zeeland, FEBS Lett., 108, 443 (1979).

13) M. Ameyama, M. Hayashi, K. Matsushita, E. Shinagawa and O. Adachi, Agric. Biol. Chem., 48, 561 (1984).

14) A. Tiselius, S. Hjerten and O. Levin, Arch. Biochem. Biophy., 65, 132 (1956).

15) M. Ameyama, E. Shinagawa, K. Matsushita and O. Adachi, Agric. Biol. Chem., 48, 3099 (1984).

16) M. Ameyama, E. Shinagawa, K. Matsushita and O. Adachi, Agric. Biol. Chem., 49, 1001 (1985).

17) J. R. Dulley and P. A. Grieve, Anal. Biochem., 64, 136 (1975)

18) M. Ameyama, K. Matsushita, Y. Ohno, E. Shinagawa and O. Adachi, FEBS Lett., 130, 179
(1981).

19) K. Matsushita, Y. Ohno, E. Shinagawa, O. Adachi and M. Ameyama, Agric. Biol. Chem., 46, 1007 (1982).

20) U. K. Laemmli, Nature (London), 227, 680 (1970).

21) K. Yamanaka and K. Matsumoto, Agric. Biol. Chem., 41, 467 (1977).

22) J. A. Duine, J. Frank and J. Westerlin, Biochim. Biophys. Acta, 524, 277 (1979).

23) M. Ameyama, "Methods in Enzymology," Vol. 89, ed. by W. A. Wood, Academic Press, inc., New York, 1982, p. 20.

24) O. Adachi, K. Tayama, E. Shinagawa, K. Matsuhita and M. Ameyama, Agric. Biol. Chem., 42, 2045 (1978).

25) B. J. Van Schie, J. P. Van Dijken and J. G. Kuenen, FEBS Lett., 24, 133 (1984).

26) Y. Imanaga, Y. Hirano-Sawatake, Y. AritaHashimoto, Y. Itoh-Shibouta and R. Katoh-Semba, Proc. Japan Acad., 55, Ser. B, 264 (1979).

27) S. Fujita and Y. Imanaga, J. Biochem. Soc. Jpn., 50, 1120 (1978).

28) T. E. King, "Methods in Enzymology," Vol. 9, ed. by W. A. Wood, Academic Press, Inc., New York, 1966, p. 98 .

29) J. A. Duine, J. Frank Jr. and R. Van der Meer, Arch. Microbiol., 131, 27 (1982).

30) T. Bak, Biochim. Biophys. Acta, 139, 277 (1967).

31) T. Bak, Biochim. Biophys. Acta, 146, 317 (1967).

32) C. L. Lobenstein-Verbeek, J. A. Jonogejan, J. Frank, Jr. and J. A. Duine, FEBS Lett., 140, 305 (1984). 